\title{
Effects of Chronic Renal Failure on Protein Synthesis and Albumin Messenger Ribonucleic Acid in Rat Liver
}

\author{
Mark A. Zern, S. H. Yap, Roger K. Strair, \\ George A. Kaysen, and David A. Shafritz \\ Departments of Medicine and Cell Biology and the Liver \\ Research Center, Albert Einstein College of Medicine, Bronx, \\ New York 10461; Department of Medicine, St. Radboud \\ Hospital, University of Nijmegen, Nijmegen, The Netherlands; \\ and Department of Medicine, University of California at \\ San Francisco, San Francisco, California 94143
}

bstract. Previously we reported that chronic renal failure in rats leads to preferential disaggregation of liver membrane-bound polysomes associated with a decrease in albumin synthesis. To determine whether reduced albumin synthesis results from reduced cellular levels of albumin messenger RNA (mRNA) or some other molecular mechanism, we have employed mRNA-DNA hybridization in conjunction with cell-free protein synthesis to determine albumin mRNA sequence content and biological activity in subcellular fractions from control and uremic rat liver. Using high specific activity albumin $\left[{ }^{3} \mathrm{H}\right]$-complementary DNA prepared from purified-albumin mRNA, we found that total liver polysomes and albumin mRNA sequence content are increased in uremic animals. The extra polysomes are located within the membrane-bound subcellular fraction. These polysomes, however, have reduced ability to synthesize albumin in the cell-free system, and mRNA isolated from membranebound polysomes of uremic liver showed reduced albumin synthesis. Evaluation of albumin mRNA size by hybridization analysis revealed a reduced content of intact albumin mRNA molecules per microgram of RNA in the

A preliminary report of this work has been previously published in abstract form in 1981, Hepatology, 1:561(Abstr.), and was presented at a meeting of the American Association for the Study of Liver Diseases, Chicago, IL, 7 November 1981.

Dr. Zern is a recipient of a Clinical Investigator Award, 1K08AM01094-01, and an American Gastroenterological Association Interdisciplinary Research Training Award. 1984.

Received for publication 23 May 1983 and in revised form 5 January

J. Clin. Invest.

(C) The American Society for Clinical Investigation, Inc.

0021-9738/84/04/1167/08 $\$ 1.00$

Volume 73, April 1984, 1167-1174 liver of uremic animals. This was associated with increased ribonuclease activity in uremic cytosol. The diminished albumin synthesis by membrane-bound polysomes of uremic rat liver can, therefore, be explained by enhanced degradation of albumin mRNA.

\section{Introduction}

Both a reduction in serum albumin and a decrease in albumin catabolism have been reported in patients with chronic renal failure (1-3). In these patients, hypoalbuminemia does not lead to a compensatory increase in albumin synthesis (1). Other studies have reported suppression of albumin synthesis in patients with chronic renal failure and improvement in both the albumin synthesis rate and serum albumin level after hemodialysis (2). The mechanism for this response, however, has not been established, although it was assumed to be secondary to improved nutrition (2).

In a rat model for chronic renal failure, Black et al. (4) reported structural and functional changes in hepatic subcellular membranes, including degranulation of the rough endoplasmic reticulum and an increase in autophagic vacuoles. Utilizing this model, we previously reported that chronic uremia causes a decrease in both albumin synthesis and total protein synthesis and a concomitant disaggregation of liver membrane-bound polyribosome complexes (5). This was not surprising because membrane-bound polyribosomes are known to synthesize secreted proteins, such as albumin, but it did not establish whether decreased albumin synthesis resulted from reduced levels or activity of albumin mRNA or a reduced function of membranebound polysomes containing normal levels of albumin messenger RNA (mRNA).

This question has been examined by quantitative analysis of albumin mRNA sequences in liver polysome fractions, using cell-free translation of liver mRNA in a messenger-dependent reticulocyte lysate system and molecular hybridization with purified $\left[{ }^{3} \mathrm{H}\right]$-complementary DNA (cDNA) or a $\left[{ }^{32} \mathrm{P}\right]$-labeled, 
cloned, recombinant albumin cDNA probe (pBRalb 149). ${ }^{1}$ Utilizing these approaches, we find that in chronic uremia there is an increase in total membrane-bound polysomes in the hepatocyte, a normal concentration of albumin mRNA sequences, but a decrease in full-length albumin mRNA molecules. This degradation of albumin mRNA is associated with an increase in ribonuclease activity in uremic rat liver cytosol and a decrease in albumin synthesis in the cell-free system. From these studies, we hypothesize that the uremic rat liver may compensate for accelerated albumin mRNA degradation by increasing the steady-state level of membrane-bound polysomes and albumin mRNA production.

\section{Methods}

Preparation of animals. Male Sprague-Dawley rats, $180-220 \mathrm{~g}$ (Holzmann Farms), rendered azotemic by surgical removal of the right kidney and segmental infarction of the left kidney, were housed and fed as previously reported (5). Both control and uremic animals were killed 1-3 mo after surgery. Only those rats with a normal weight gain, a reduced serum albumin level, and a blood-urea nitrogen level of $>60 \mathrm{mg} / 100 \mathrm{ml}$ were utilized as uremic.

Isolation of membrane-bound and free liver polysomes. Animals were killed by cervical dislocation. Livers were removed rapidly, weighed and perfused with $200 \mathrm{ml}$ of cold $250 \mathrm{mM}$ sucrose; $1 \mathrm{mM} \mathrm{MgCl}_{2} ; 300 \mu \mathrm{g} /$ $\mathrm{ml}$ sodium heparin, followed by $100 \mathrm{ml}$ of cold homogenizing buffer (250 mM sucrose; $50 \mathrm{mM} N$-2-hydroxyethylpiperazine- $N^{\prime}-2$ ethanesulfonic acid (Hepes), pH 7.4; $75 \mathrm{mM} \mathrm{KCl} ; 5 \mathrm{mM} \mathrm{Mg} \mathrm{Cl}$; 1 mM dithiothreitol). Membrane-bound and free liver polysomes were prepared according to the quantitative procedure of Ramsey and Steele (6), as described elsewhere $(7,8)$. This procedure utilizes both heparin and rat liver cell sap as inhibitors of ribonuclease activity. In addition, adenosine $2^{\prime} 3^{\prime}$-cyclic monophosphate and vanadyl sulfate were employed as ribonuclease inhibitors during the homogenization steps. This resulted in improved protein synthesis activity of mRNA isolated from rat liver polysomes. Isolated membrane-bound or free liver polyribosomes were evaluated for size by sucrose gradient analysis and used for cell-free protein synthesis. Alternatively, total RNA was isolated from the polysomes by a phenol:chloroform:isoamyl alcohol extraction procedure followed by ethanol precipitation (7).

In vitro protein synthesis with intact liver polyribosomes. Incubations were performed, as previously described (9), for $15 \mathrm{~min}$ at $30^{\circ} \mathrm{C}$ and contained $20 \mathrm{mM}$ Tris- $\mathrm{HCl}, \mathrm{pH} 7.4 ; 1.0 \mathrm{mM}$ adenosine triphosphate; $0.2 \mathrm{mM}$ guanosine triphosphate; $15 \mathrm{mM}$ creatine phosphate; $60 \mu \mathrm{g} / \mathrm{ml}$ of creatine phosphokinase; $7 \times 10^{-5} \mathrm{M}$ amino acids less leucine; 1.5 $\times 10^{-5} \mathrm{M}$ leucine (L-[4,5- $\left.{ }^{3} \mathrm{H}\right]$ leucine, sp act $50 \mathrm{Ci} / \mathrm{mmol}$ (Amersham, England); $1 \mathrm{mM}$ dithiothreitol; $3 \mathrm{mM} \mathrm{MgCl}{ }_{2} ; 80 \mathrm{mM} \mathrm{K}^{+}$acetate; $3 \mu \mathrm{l}$ of $105,000 \mathrm{~g}$ supernatant protein; and $0.4 A_{260}$ units of free or membranebound polysomes. Incorporation of $\left[{ }^{3} \mathrm{H}\right]$ leucine into proteins was measured by liquid scintillation spectroscopy of trichloroacetic acid-precipitated material. Under the conditions employed, amino acid incorporation was linear with time for 20-30 min.

1. Abbreviations used in this paper: $\mathrm{pBRalb} 149$, numerical designation of cloned, recombinant albumin cDNA probe; poly $\mathrm{A}^{+}$mRNA, polyadenylated mRNA isolated from polyribosomes by phenol extraction and oligo (dT)-cellulose chromatography; RNAse, ribonuclease.
Preparation of purified albumin $m R N A$ and albumin $\left[{ }^{3} H\right]-c D N A$. Purification of albumin mRNA was performed as previously reported $(7,10)$. The major steps in this procedure included immunoprecipitation of polysomes containing albumin nascent chains, isolation of polyadenylated RNA (poly $A^{+}$mRNA) from these polyribosomes by phenol extraction and oligo [deoxy-thymidine (dT)]-cellulose chromatography, and subsequent purification of albumin mRNA by controlled molecular hybridization with albumin sequence-enriched cDNA-cellulose $(7,10)$. The isolated albumin mRNA was then transcribed into albumin $\left[{ }^{3} \mathrm{H}\right] \mathrm{c}$ DNA as described (10).

$R N A-c D N A$ hybridization. Analytical RNA-cDNA hybridization was performed at $65^{\circ} \mathrm{C}$ in $5-\mu l$ sealed capillary tubes containing $0.2 \mathrm{M}$ sodium phosphate buffer, pH 6.8 and $0.5 \%$ sodium dodecyl sulfate (SDS) as previously reported (10). Hybrid formation was monitored by determining the percentage of input $\left[{ }^{3} \mathrm{H}\right]-\mathrm{cDNA}$ that remained insoluble in $10 \%$ trichloroacetic acid (TCA) after digestion with $S_{1}$ nuclease (10).

Extraction of cytoplasmic RNA and preparation and labeling of recombinant plasmid pBRalb 149. Total RNA was isolated from control or uremic liver by $8 \mathrm{M}$ guanidine $\mathrm{HCl}$ extraction and differential ethanol precipitation, using modifications of previously described procedures (11). Briefly, this entailed homogenization of liver in $8 \mathrm{M}$ guanidine $\mathrm{HCl}$, pH 7.0 (20 ml of guanidine per $3 \mathrm{~g}$ of tissue), discarding of centrifuged particulate matter $[5,000 \mathrm{rpm}$ for $10 \mathrm{~min}$ in an $\mathrm{HB} 4$ rotor (DuPont-Sorvall, Newtown, CT)], and precipitation of RNA from the supernatant fraction with 0.5 vol of absolute ethanol. Further purification of RNA was accomplished by phenol-chloroform-isoamyl alcohol extraction, high salt fractionation, and ethanol precipitation $(7,8)$. RNA content was determined by spectrophotometric absorption at $260 \mathrm{~nm}$.

For solid-phase hybridization studies on Gene Screen membrane (New England Nuclear, Boston, MA), albumin cDNA sequences were repurified from a recombinant rat albumin cDNA clone (pBRalb 149) (12), according to the method of Villa Kamaroff et al. (13). Briefly, the plasmids were grown in bulk in Escherichia coli HB101, isolated by $\mathrm{CsCl}$ banding, purified, ethanol-precipitated, and digested with restriction enzyme Pst $I$. The digests were then electrophoresed in $1 \%$ preparative agarose slab gels, using Dingman and Peacock buffer (14), to separate the purified inserted gene sequences from the residual linearized plasmid band. The recombinant DNA sequences were reisolated from the gel and were "nick-translated" with $\left.{ }^{32} \mathrm{P}\right]$-deoxycytidine triphosphate to a specific activity of $3-5 \times 10^{7} \mathrm{cpm} / \mu \mathrm{g}$ DNA by a modification of the procedure of Rigby et al. (15).

Spotting of RNA onto nitrocellular filter paper ("dot blot" assay). Total RNA from uremic and control mouse liver was serially diluted and dotted onto nitrocellulose paper which had been pretreated with 3 $\mathrm{M} \mathrm{NaCl}-0.3 \mathrm{M} \mathrm{Na}$ citrate (16). The dot blots were then baked in vacuo for $2 \mathrm{~h}$ at $80^{\circ} \mathrm{C}$, prehybridized for $6-20 \mathrm{~h}$, hybridized for $20-36 \mathrm{~h}$, and washed essentially as described by Thomas (16). The blots were exposed to Kodak XAR-5 film (Eastman Kodak Co., Rochester, NY) at $-70^{\circ} \mathrm{C}$.

Hybridization analysis of total RNA transferred to a membrane filter ("Northern" transfer). Total RNA was extracted from uremic and control rat liver as described above. $7 \mu \mathrm{g}$ each of uremic and control total RNA were denatured for $15 \mathrm{~min}$ at $60^{\circ} \mathrm{C}$ in buffer containing $50 \%$ deionized formamide, $6 \%$ formaldehyde, and $1 \times$ MOPS buffer: $20 \mu \mathrm{M}$ morpholinopropanesulfonic, $5 \mathrm{mM}$ sodium acetate, and $1 \mathrm{mM} \mathrm{Na}{ }_{2}$ EDTAplaced in separate lanes of a $1 \%$ agarose gel prepared in $1 \times$ MOPS buffer without $6 \%$ formaldehyde; and electrophoresed for 4-5 $\mathrm{h}$ at 100 mA. After electrophoresis, the RNA was transferred to Gene Screen, as described by the manufacturer, and hybridized with a nick-translated $\left.{ }^{32} \mathrm{P}\right]$-labeled probe. After hybridization, the membrane was washed and exposed for autoradiography at $-70^{\circ} \mathrm{C}$ on Kodak XAR-5 film. 
Preparation of fractions for ribonuclease (RNAse) determination. Uremic and control rats were killed by cervical dislocation and livers were perfused with $250 \mathrm{mM}$ sucrose- $1 \mathrm{mM} \mathrm{MgCl}$, followed by homogenizing buffer (see above). The livers were then homogenized in 3 vol of homogenizing buffer and centrifuged in an HB4 rotor at 2,000 $\mathrm{rpm}$ for $3 \mathrm{~min}$ and $10,000 \mathrm{rpm}$ for $10 \mathrm{~min}$ to remove cellular debris and nuclei. The supernatant fraction was centrifuged at 55,000 rpm at $4^{\circ} \mathrm{C}$ for $3 \mathrm{~h}$ in a Beckman No. 65 rotor (Beckman Instruments, Inc., Fullerton, CA), and the resulting cytosolic fraction saved for RNAse determination. The membrane rich pellet was dissolved in homogenizing buffer, adjusted to $1 \%$ in Triton X-100, and centrifuged at $58,000 \mathrm{rpm}$ at $4^{\circ} \mathrm{C}$ for $2 \mathrm{~h}$. The detergent solubilized membrane fraction was utilized for RNAse determination. 1\% Triton X-100 did not inhibit RNAse activity in liver cytosol.

Equal amounts of protein [as determined by the Bio-Rad (Bio-Rad Laboratories, Richmond, CA) protein assay (17)] from control and uremic liver cytosol and solubilized membrane fractions were employed in an RNAse assay. $\left[{ }^{3} \mathrm{H}\right]$-labeled HeLa cell poly $\mathrm{A}^{+}$mRNA (10-30S) was incubated for $30 \mathrm{~min}$ at $27^{\circ} \mathrm{C}$ in a solution containing $10 \mathrm{mM}$ Tris$\mathrm{HCl}\left(\mathrm{pH} \mathrm{7.4),} 200 \mathrm{mM} \mathrm{NaCl}\right.$, and $5 \mathrm{mM} \mathrm{MgCl}_{2}$ and the protein fractions as described above. Pancreatic RNAse $(25 \mu \mathrm{g} / \mathrm{ml})$ was used as a control. After incubation, the reaction mixture was layered immediately over a 12-ml, 5-20\% exponential sucrose gradient, which contained $10 \mathrm{mM}$ Tris- $\mathrm{HCl}$ (pH 7.4), $0.5 \% \mathrm{SDS}$, and $3 \mathrm{mM} \mathrm{Na} 2$ EDTA. Centrifugation was performed at $34,000 \mathrm{rpm}$ in a Beckman SW41 rotor (Beckman Instruments Inc.) for $15.5 \mathrm{~h}$. Gradients were withdrawn from the bottom of each tube and the position of rabbit ribosomal RNA markers was determined in a parallel gradient. Fractions of $0.5 \mathrm{ml}$ were collected and evaluated for radioactivity by liquid scintillation spectrophotometry.

The ability of liver cytosol fractions to degrade rat albumin mRNA was also evaluated. $5 \mu \mathrm{g}$ of poly $\mathrm{A}^{+}$RNA extracted from membranebound poyribosomes of control rat liver was incubated with equal amounts of cytosolic protein from control and uremic liver as described above. After incubation for $30 \mathrm{~min}$ at $27^{\circ} \mathrm{C}$, the mRNA was reisolated by phenol:chloroform:isoamyl alcohol extraction followed by ethanol precipitation (7). Degradation of specific albumin mRNA was evaluated by gel electrophoresis of the extracted RNA, transfer to a Gene Screen filter, and hybridization with [ $\left.{ }^{32} \mathrm{P}\right]$-labeled pBRalb 149.

\section{Results}

Previously, we observed that the average size of polyribosomes in rat liver was decreased in uremia (5) and that this effect was most pronounced with membrane-bound polysomes. In order

Table I. Yield and Subcellular Distribution of Liver Polysomes from Control and Uremic Rats

\begin{tabular}{llllrl}
\hline & & & \multicolumn{2}{c}{ Polysomal RNA } & \\
& $\begin{array}{lllll}\text { Body } \\
\text { weight }\end{array}$ & $\begin{array}{l}\text { Liver } \\
\text { weight }\end{array}$ & $\begin{array}{l}\text { Membrane- } \\
\text { bound }\end{array}$ & Free & $\begin{array}{l}\text { Membrane- } \\
\text { bound/free }\end{array}$ \\
\hline & $g$ & $g$ & $\mu g / g$ liver & $\mu g / g$ liver & \\
Control & 370 & 13 & 3,754 & 911 & 4.1 \\
Uremic & 345 & 11.5 & 5,979 & 1,120 & 5.3 \\
\hline
\end{tabular}

Each experiment comprised two animals in each group.
Table II. Cell-free Protein Synthesis by Control and Uremic Rat Liver Polysomes

\begin{tabular}{llc}
\hline & & $c p m / \mu g R N A$ \\
Membrane-bound & Uremic $^{*}$ & $590 \pm 70$ \\
& Control $^{*}$ & $940 \pm 130$ \\
Free & Uremic & $1100 \pm 190$ \\
& Control & $1180 \pm 140$ \\
\hline
\end{tabular}

Three separate experiments were performed. Significance was determined by Student's $t$ test. Means \pm SE.

$* P<0.02$.

to analyze albumin mRNA in liver membrane-bound and free polysomes from uremic vs. control animals, we employed quantitative methods of polysome isolation (6) and were able to recover $\sim 80-90 \%$ of total polysomal RNA. This was determined in both control and uremic animals by comparing the combined yield of membrane-bound and free polysomal RNA to total RNA from the postnuclear supernatant fraction. As shown in Table I, there is an increase in total polysomal RNA in uremic liver. This finding has been confirmed independently by isolating total polysomal RNA from whole liver, in which case there was significantly more RNA per gram of liver in uremic vs. control animals $(4.85 \pm 0.34 \mathrm{SD}$ vs. $3.68 \pm 0.25 \mu \mathrm{g} / \mathrm{g}$ liver, $P<0.05$, Student's $t$ test, $n=4)$. Normally, the ratio of membrane-bound/ free polysomes is $3.5-4.0: 1(7,8)$. In uremic animals, this ratio was increased to $\sim 5: 1$ (Table I).

The ability of liver membrane-bound and free polysomes to synthesize protein and albumin was tested in a cell-free system (5). As shown in Table II, there was a $37.2 \%$ decrease in amino acid incorporation (counts per minute incorporated into protein/ microgram of polysomal RNA added) with membrane-bound polysomes from uremic animals. The ability to synthesize albumin (i.e., material with immunologic properties and molecular weight of albumin) was affected even more dramatically. As shown in Table III, albumin synthesis was reduced by $45.2 \%$. Therefore, total production of albumin by uremic membranebound polysomes was $34 \%$ of that of control animals.

To delineate further the defect in the molecular machinery responsible for reduced in vitro protein synthesis in uremic liver, total RNA was extracted from the polyribosomes and translated in an mRNA-dependent rabbit reticulocyte system. As shown in Table IV, RNA from free polysomes incorporated more $\left[{ }^{35}\right.$ S]methionine than did polysomal RNA from membrane-bound polyribosomes. In addition, RNA extracted from membrane-bound polysomes of control animals was three times more efficient in protein synthesis than was RNA from membrane-bound polysomes of uremic animals (Table IV).

To characterize the effect of uremia on specific protein synthesis, we applied equal amounts of TCA insoluble polypeptide, obtained from translation of total cellular RNA (prepared by guanidine $\mathrm{HCl}$ extraction) in the reticulocyte lysate system, to 
Table III. Synthesis of Albumin by Liver Membrane-bound and Free Polysomes from Control vs. Uremic Rats

\begin{tabular}{lll}
\hline Polyribosomes & & Albumin synthesis \\
\hline \multirow{3}{*}{ Membrane-bound } & Control & $4.04 \pm 0.35^{*}$ \\
& Uremic & $2.23 \pm 0.76^{*}$ \\
Free & Control & $0.94 \pm 0.41$ \\
& Uremic & $0.88 \pm 0.24$ \\
\hline
\end{tabular}

Protein synthesis with intact liver polyribosomes was performed as described in Methods but with a larger reaction volume $(0.5-1.0 \mathrm{ml})$, and after synthesis the incubation mixture was centrifuged at 60,000 $\mathrm{rpm}$ for $2 \mathrm{~h}$ at $2^{\circ} \mathrm{C}$. Incorporation of $\left[{ }^{3} \mathrm{H}\right]$ leucine into protein was measured in a small aliquot of the supernatant fraction by liquid scintillation spectroscopy of hot TCA-precipitated material. Albumin synthesis was determined in the remainder of the supernatant fraction by indirect immunoprecipitation as previously described (5) and SDS gel electrophoresis. The gel was fractionated and counts per minute co-migrating with an albumin standard at $68,000 \mathrm{D}$ was compared to total TCA-precipitated material. Means \pm SD.

$* P<0.05$. Four separate experiments were performed. Significance was determined by Student's $t$ test.

an SDS-polyacrylamide gel. In separate preparations from two sets of animals, there was a decrease in albumin production with mRNA from uremic animals (Fig. 1). This experiment in a heterologous translation system with isolated mRNA is consistent with results obtained in the liver polyribosome system (Tables II and III) and provides additional evidence for a disproportionate reduction in albumin synthesis as compared to total proteins in uremic rat liver. Quantitative changes in synthesis of other proteins, two of which are more intensely labeled in uremic liver as compared to control, were also noted (Fig. 1). However, the nature of these products has not been identified.

Albumin mRNA sequence content in RNA extracts from membrane-bound and free polysomes of control versus uremic rat liver was determined by molecular hybridization in solution $(7,10)$. The amount of RNA required to produce $50 \%$ hybridization can be used to obtain the relative concentration of albumin mRNA in various RNA preparations (10). As shown in Fig. 2, control and uremic polysomal RNA gave almost identical saturation curves for both the membrane-bound and free polysomal RNA fractions. As previously observed (7), membranebound polysomes had a 16-times greater content of albumin mRNA sequences than free polysomes.

To compute the total subcellular distribution of albumin mRNA sequences in membrane-bound and free polysomes, the relative proportion of albumin mRNA in each fraction (Fig. 2) is multiplied by the distribution ratio of membrane-bound to free polysomes in the same preparation (Table I). If the absolute concentration of RNA per microgram of liver and the albuminspecific sequences per microgram of RNA are also known, then the total content of albumin mRNA per gram of liver can be computed. Since $1 \mathrm{pg}$ of purified albumin mRNA hybridizes with $5 \mathrm{cpm}$ of albumin $\left[{ }^{3} \mathrm{H}\right] \mathrm{cDNA}$ labeled to a specific activity of $5 \times 10^{6} \mathrm{cpm} / \mu \mathrm{g}$, the absolute content of albumin mRNA in all subcellular fractions can be computed (7). As shown in Table $\mathrm{V}$, the distribution ratio and concentration of albumin mRNA sequences in uremic membrane-bound and free polysomes is unchanged from control values. However, since the amount of membrane-bound polysomes is increased in uremia (Table I), the total amount of albumin mRNA in membrane-bound polysomes is increased (from $548 \mathrm{ng} / \mathrm{g}$ in control liver to $873 \mathrm{ng} / \mathrm{g}$ in uremic liver, Table V).

One possible explanation for the marked decrease in albumin synthesis, yet normal concentration (and increased content) of albumin mRNA sequences, would be degradation of the albumin mRNA in uremic liver. To evaluate this possibility, we extracted total RNA from rat liver by the $8 \mathrm{M}$ guanidine $\mathrm{HCl}$ method, which has been found particularly useful for isolating biologically intact mRNA from a variety of tissues $(11,20,21)$. Total RNA was extracted and analyzed for albumin mRNA content by

Table IV. Translation of Total Liver RNA Extracted from Polysomes of Control and Uremic Rats in a Reticulocyte mRNA-dependent Cell-free System*

\begin{tabular}{lc}
\hline Sample & $\begin{array}{l}\text { [ }^{35} \text { S]Methionine } \\
\text { incorporation } \\
\text { into protein }\end{array}$ \\
\hline & $c p m / 5 \mu l$ \\
Untreated lysate & 566,945 \\
mRNA-dependent lysate & 21,975 \\
+ uremic bound polysomal RNA $(20 \mu \mathrm{g})$ & 51,844 \\
+ control bound polysomal RNA $(20 \mu \mathrm{g})$ & 117,838 \\
+ uremic free polysomal RNA $(10 \mu \mathrm{g})$ & 209,020 \\
+ control free polysomal RNA $(10 \mu \mathrm{g})$ & 190,842 \\
+ total rat liver poly A ${ }^{+}$mRNA $(1 \mu \mathrm{g})$ & 206,259 \\
\end{tabular}

mRNA-dependent rabbit reticulocyte lysate was prepared by digestion with micrococcal nuclease according to the procedure of Pelham and Jackson (18). Incubations in a total volume of $25 \mu \mathrm{l}$ were performed at $26^{\circ} \mathrm{C}$ for $60 \mathrm{~min}$ and contained $12.5 \mu \mathrm{l}$ lysate, $0.5 \mathrm{mM}$ ATP, $0.1 \mathrm{mM}$ GTP, $10 \mathrm{mM}$ phosphocreatine, $60 \mu \mathrm{g} / \mathrm{ml}$ creatine phosphokinase, $100 \mathrm{mM} \mathrm{KCl}, 2 \mathrm{mM} \mathrm{Mg}$ acetate, $10 \mathrm{mM}$ Hepes, $\mathrm{pH}$ $7.4,2.0 \times 10^{-5} \mathrm{M} 19$ amino acids less methionine, $15-25 \mu \mathrm{Ci}$ of $\left.{ }^{35} \mathrm{~S}\right]$ methionine (sp act $\sim 600 \mathrm{Ci} / \mathrm{mmol}$ ) (Amersham, England) and mRNA as indicated. Rat liver mRNA was prepared by SDS-phenol extraction of total nucleic acids from whole liver, followed by $3 \mathrm{M}$ $\mathrm{NaCl}$ precipitation to remove DNA and ethanol precipitation of RNA. Total poly $\mathrm{A}^{+}$mRNA was prepared by oligo dT-cellulose chromatography. Membrane-bound and free polysomal RNA were extracted from polysomes as described in Methods. Incorporation of $\left.{ }^{[3} \mathrm{S}\right]$ methionine into protein was determined on a 5- $\mu \mathrm{l}$ aliquot as hot TCA-insoluble material (5). Under the conditions used, amino acid incorporation increased linearly for $>\mathbf{9 0} \mathrm{min}$ and added mRNA was the rate-limiting component in the system.

* Results from three separate experiments gave similar findings. 


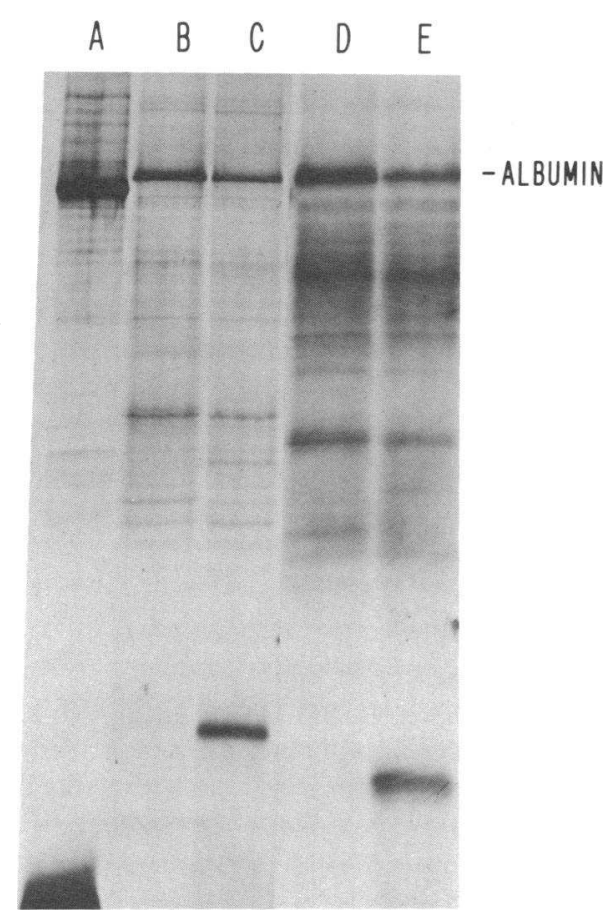

Figure 1. Identification of albumin in the cell-free reaction product of mRNA-dependent reticulocyte lysate under the direction of control vs. uremic liver RNA. $3.0 \mu \mathrm{l}$ of the cell-free reaction products under direction of total cellular RNA extracted by guanidine $\mathrm{HCl}$ and translated in the reticulocyte lysate system were applied to a $12 \%$ SDS-polyacrylamide slab gel and electrophoresed as reported by Shields and Blobel (19). $\sim 60,000 \mathrm{cpm}$ of TCA-insoluble material were applied to each lane. Slot $A$ represents proteins synthesized from undigested rabbit reticulocyte lysate; slots $B$ and $C$ represent cell-free products synthesized under the direction of control $(B)$ vs. uremic $(C)$ RNA prepared simultaneously from pair-fed animals. Slots $D$ and $E$ represent results of a separate experiment with other simultaneously prepared control $(D)$ and uremic $(E)$ RNAs from pair-fed control vs. uremic animals. The position of a rat albumin standard (mol wt 68,000 D) is identified.

"dot" hybridization. As shown in Fig. 3, when equal amounts of total RNA was dotted onto nitrocellulose paper and hybridized with a nick-translated, cloned-albumin cDNA probe, there was no difference in albumin mRNA sequence content between control (lane CON) and uremic (lane UR) liver. This confirmed previous findings by quantitative solution hybridization (Table V). However, when RNA from the control and uremic rat liver was analyzed for albumin mRNA size by agarose gel electrophoresis, followed by Northern transfer and hybridization with cloned repurified $\left[{ }^{32} \mathrm{P}\right]$-labeled pBRalb 149 (Fig. 4), there was a marked dimunition of full-sized albumin mRNA in uremic liver RNA (lanes B and D) as compared with companion preparations from control liver RNA (lanes $A$ and $C$ ). These results suggest that albumin mRNA degradation may explain decreased albumin synthesis in the cell-free system with uremic liver

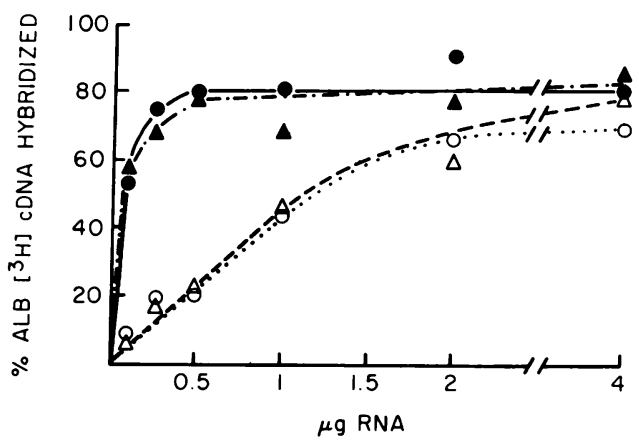

Figure 2. Solution hybridization analysis of RNA extracted from liver membrane-bound and free polysomes of control and uremic rats. RNA from control membrane-bound polysomes $(\bullet-\bullet)$, uremic membrane-bound polysomes $(\Delta-\cdot-\cdot \Delta)$, control free polysomes $(0 \cdots \cdots \circ)$, or uremic free polysomes $(\Delta \cdots \cdot-\cdot \Delta)$, was hybridized to $400 \mathrm{cpm}$ of albumin $\left[{ }^{3} \mathrm{H}\right] \mathrm{cDNA}$ in $0.2 \mathrm{M}$ Na phosphate buffer (pH 6.8)-0.5\% SDS for $40 \mathrm{~h}$ at $65^{\circ} \mathrm{C}$ in a sealed 5- $\mu$ l capillary tube. Samples were diluted into $2 \mathrm{ml}$ of $\mathrm{S}_{1}$ digestion buffer and processed for hybrid formation as noted in Methods.

membrane-bound polysomes. When total RNA extracted by the guanidine $\mathrm{HCl}$ technique was employed in the cell-free system, decreased albumin and total protein synthesis was found in uremic as compared to control liver RNA (data not shown).

Because previous ultrastructural studies had shown an increase in lysosomes and autophagic vacuoles in the liver of rats with chronic renal failure (4) and RNAses are known to be present in lysosomes (22), we assayed various subcellular fractions for RNAse activity. When labeled mRNA was incubated with soluble extracts from uremic vs. control animals (either a cytosolic or detergent-treated microsomal fraction), the uremic samples digested the mRNA more completely than did the control extracts. When the digested material was layered over an exponential sucrose gradient, the uremic samples showed greater RNAse activity (degradation of $\left[{ }^{3} \mathrm{H}\right]$-labeled HeLa cell mRNA) per microgram of total protein with either the cytosolic fraction (Fig. $5 \mathrm{~A}$ ) or the detergent-solubilized microsomal fraction (Fig.

Table V. Distribution of Albumin mRNA Sequences in Liver Polyribosomes from Control $v$ s. Uremic Rats

\begin{tabular}{cccc}
\hline & \multicolumn{3}{c}{ Polyribosome fraction } \\
\cline { 2 - 4 } & Membrane-bound & Free \\
\hline Albumin mRNA sequence & Control & 97 & 3 \\
(\% total albumin mRNA) & Uremic & 98 & 2 \\
Albumin mRNA concentration & Control & 146 & 18 \\
$(p g / \mu g$ RNA) & Uremic & 146 & 18 \\
Albumin mRNA content & Control & 548 & 16 \\
$($ ng/g liver $)$ & Uremic & 873 & 20 \\
\hline
\end{tabular}




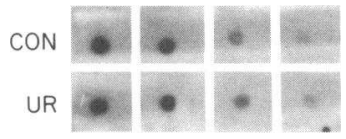

Figure 3. Dot-blot analysis of RNA isolated from liver of control and uremic rats on nitrocellulose paper and hybridized with an albumin probe. RNA from control (CON) and uremic (UR) liver were serially diluted and spotted on nitrocellulose paper as previously described (16) and summarized in Methods. Equally intense signals were found when $0.75,0.3,0.075$, and 0.015 $\mu \mathrm{g}$ of RNA from control and uremic liver, respectively, were hybridized with pBRalb 149. The dilution of each sample is from left to right on the respective rows.

$5 \mathrm{~B})$. Uremic cytosol also showed greater ability to degrade albumin mRNA as compared to control cytosol (Fig. 6). When rat liver poly $\mathrm{A}^{+}$RNA was incubated with uremic vs. control cytosol and the mRNA was subsequently analyzed for albumin mRNA sequences by agarose gel electrophoresis and hybridization with a $\left[{ }^{32} \mathrm{P}\right]$ albumin DNA probe, uremic cytosol produced more degradation of albumin mRNA (lanes B, D, and F) than did comparable amounts of control cytosol (lanes $C$, $\mathrm{E}$, and $\mathrm{G})$.

\section{Discussion}

Scattered reports of abnormalities in serum protein synthesis in patients with chronic renal failure $(1,2)$ and electron microscopic evidence for degranulation of liver rough endoplasmic reticulum (4) in uremic rats prompted us to study in vitro protein synthesis in the rat model of chronic renal failure. Using this system, we previously reported a preferential disaggregation of membrane-bound polysomes, a decrease in albumin synthesis by uremic membrane-bound polysomes and intracellular accumulation of albumin in the uremic rat hepatocyte (5).

To explain these results, it was necessary to obtain quantitative information on the level and subcellular distribution of albumin mRNA. Although previous studies have utilized in vitro protein synthesis to measure specific mRNA, it is clear that variations in experimental conditions may influence translation of specific eukaryotic mRNAs (24), including albumin

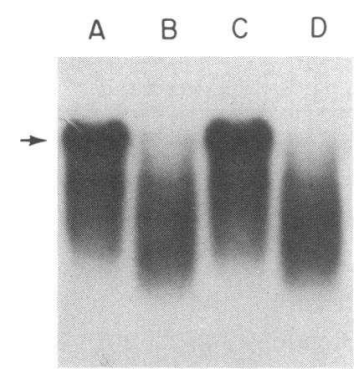

Figure 4. Size of RNA molecules containing albumin mRNA sequences from control and uremic rat liver membrane-bound polysomes. Total RNA was extracted from homogenized liver, denatured, electrophoresed, transferred to a Gene Screen membrane filter, hybridized with a recombinant cloned, purified $\left[{ }^{32} \mathrm{P}\right]-$ labeled albumin DNA probe, and autoradiographed as described in Meth-

ods. Lanes $A$ and $C$ represent two separate control RNA samples and lanes $B$ and $D$ their companion uremic RNA samples. The arrow represents the location of full-sized albumin mRNA.

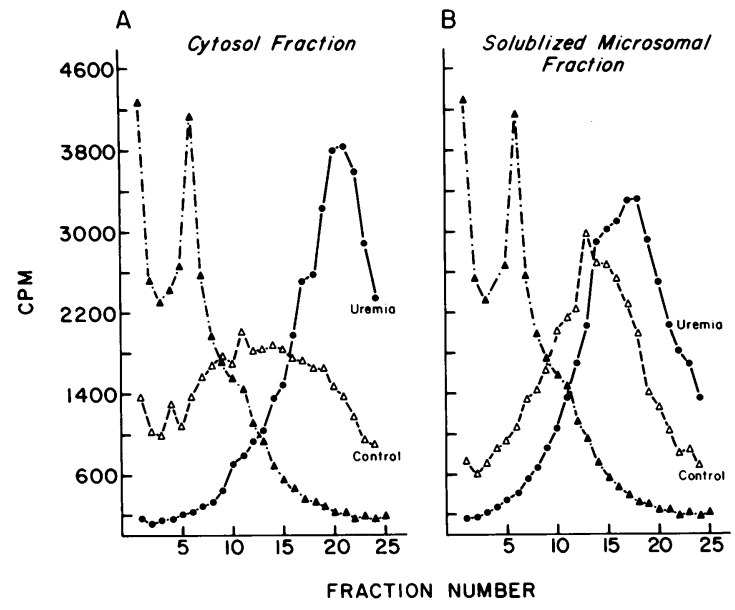

Figure 5. Assay of RNAse activity in uremic and control rat liver. Undigested $\left[{ }^{3} \mathrm{H}\right]$ HeLa cell poly $A^{+}$RNA $(\Delta-\cdot-\cdot \Delta)$, or $\left[{ }^{3} \mathrm{H}\right]$ Hela cell poly $\mathrm{A}^{+} \mathrm{RNA}$ incubated with extracts $(0.8 \mu \mathrm{g}$ of protein) from the $(A)$ cytosol or $(B)$ detergent solubilized microsomes from uremic $(\bullet-\bullet)$ or control $(\Delta--\Delta)$ liver. The reaction mixtures were layered over a $5-20 \%$ exponential sucrose gradient, centrifuged, and counted by liquid scintillation spectroscopy as described in Methods. The direction of sedimentation is from right to left. The peak position of $18 \mathrm{~S}$ ribosomal RNA marker was in fraction 4.

(25). Therefore, we employed both cell-free protein synthesis and mRNA-DNA molecular hybridization to analyze albumin mRNA in extracts from membrane-bound and free liver poly-

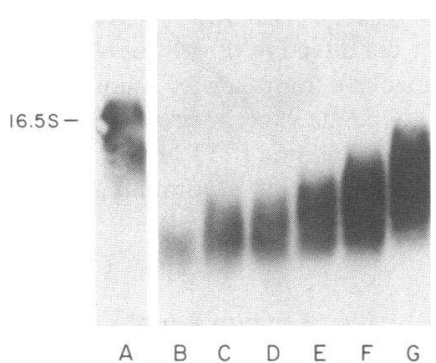

Figure 6. Assay of RNAse activity in uremic and control rat liver cytosol fraction using albumin mRNA as substrate. Rat liver poly $\mathrm{A}^{+}$ RNA was either undigested or incubated with liver cytosolic extracts from uremic or control animals as noted in Methods. The RNA was reisolated from the reaction

mixture by phenol extraction and ethanol precipitation, denatured for $1 \mathrm{~h}$ at $50^{\circ} \mathrm{C}$ in buffer containing $1.5 \mathrm{M}$ glyoxyl, $75 \%$ dimethyl sulfoxide, $10 \mathrm{mM} \mathrm{NaH}_{2} \mathrm{PO}_{4}, 10 \mathrm{mM} \mathrm{Na} \mathrm{HPO}_{4}$ (23), placed in separate lanes of a $0.8 \%$ agarose slab gel, and electrophoresed in Dingham and Peacock buffer (14) for 4-5 h at $65 \mathrm{~V}$. After electrophoresis, the RNA was transferred to Gene Screen, as described by the manufacturer, hybridized with the nick-translated $\left[{ }^{32} \mathrm{P}\right]$-labeled albumin cDNA probe. After hybridization, the Gene Screen filter was exposed to autoradiography at $-70^{\circ} \mathrm{C}$ on Kodak XAR-5 film. Lane $A$ represents control rat liver poly $\mathrm{A}^{+}$mRNA; lanes $B, D$, and $F$ represent this RNA incubated with $1.6,0.4$, and $0.2 \mu \mathrm{g}$ of liver cytosolic protein extracts from uremic animals, and lanes $C, E$, and $G$ represent paired RNA samples incubated with equal amounts of liver cytosolic protein from control animals. 
somes $(7,10)$. We employed both albumin $\left[{ }^{3} \mathrm{H}\right] \mathrm{cDNA}$ and recombinant cloned albumin $\left[{ }^{32} \mathrm{P}\right] \mathrm{DNA}$ probes to evaluate qualitative and quantitative aspects of albumin sequence content. Hybridization results indicated that there was no difference in the albumin mRNA sequence content per microgram of RNA in uremic animals, despite decreases in albumin synthesis by uremic membrane-bound polysomal RNA.

However, interpretation of these results was limited because solution hybridization provides no information concerning the intactness of molecules containing specific nucleic acid sequences. To address this issue, we used affinity hybridization of a [ $\left.{ }^{32} \mathrm{P}\right]$-labeled albumin cDNA probe to RNA electrophoresed through an agarose gel and transferred to a membrane filter (Northern transfer). Although this latter technique is not quantitative, it provides important information on the size (or intact nature) of molecules containing albumin mRNA sequences. This technique indicated a dimunition of full-sized albumin mRNA in uremic liver and, therefore, provides an explanation for why albumin synthesis might be diminished in uremic animals, despite the apparently normal albumin mRNA sequence content.

The finding of increased RNAse activity in uremic rat liver cytosol and microsomal fractions provided insight into the cause of albumin mRNA degradation. In uremic rat liver, Black et al. (4) demonstrated an increased content of autophagic vacuoles and lysosomes, which contained subcellular organelles in various states of degradation. Other authors have found an increase in ribonuclease activity in various pathophysiological states, including protein-calorie malnutrition (26) and hypophysectomy (27). In that RNAses are enriched in the lysosomal fraction (22), it is possible that lysosomal activation or fragility of lysosomal vesicles in uremia results in increased RNAse activity, which in turn adversely effects protein synthesis. The finding that albumin mRNA stability may be a crucial factor in regulating the synthesis of this protein in vitro has been demonstrated in another rat model system (12). In rats chronically fed ethanol, we have found an increase in the in vitro synthesis of albumin and other exported proteins, and gel electrophoresisfilter hybridization experiments showed that ethanol administration was associated with an increase in intact albumin mRNA (12).

A major question in studying the molecular basis for abnormalities in protein synthesis in animals under altered physiologic or pathologic conditions is the influence of nutritional factors on polysome function. It has been established both in vivo and in vitro that amino acid supply plays a unique role in regulating protein synthesis (28-32). This is particularly important in patients with uremia, because it has been concluded that derangements of hepatic protein synthesis in this syndrome are secondary to dietary protein deficiency (2). It has also been assumed that clinical improvement of patients after hemodialysis results primarily from improved dietary intake (2). In patients, nutrition may indeed be a primary factor, but in our studies of uremic rats we have eliminated nutritional differences and still find specific abnormalities in hepatic protein synthesis (5). In rat liver, the effect of fasting on protein synthesis and albumin mRNA is different from the effect of uremia. In rats fasted for 24-30 h, we have found a decrease in total liver polysomes, a decrease in total liver albumin mRNA, and a shift of remaining albumin mRNA into nontranslated cytoplasmic mRNA-protein complexes (8). Other investigators have found that chronic protein-calorie deprivation in rats causes a decrease in liver RNA, a disaggregation of polysomes, and a decrease in hepatic protein synthesis (33).

In chronic uremia, we found an increase in total liver polysomal RNA, range: $25-50 \%$. There was also an increase in the ratio of membrane bound/free polyribosomes, but a normal concentration and subcellular distribution of albumin mRNA sequences. These findings are distinct from our previous findings in fasted rat liver, suggesting a different subcellular mechanism. With uremia, we propose a relative block in albumin synthesis in liver membrane-bound polysomes related to partial degradation of albumin mRNA. We do not mean to imply that these effects are specific for this mRNA, but rather that albumin may serve as an example for decreased synthesis of an exported protein which is synthesized on liver membrane-bound polysomes (34).

It seems reasonable then to consider that uremia may be influencing the expression of the albumin gene at several posttranscriptional points. This observation is not unique, in that changes in specific mRNA half-life with induction, hormonal changes, or cellular differentiation have been demonstrated in several system (35-37). In our rat model, uremia seems to influence albumin synthesis by an increased degradation of albumin mRNA by an apparent stimulation of ribonuclease activity. This may be partially offset by an increased steady-state level of albumin mRNA in the cell, a significant portion of which is degraded. The efficient expression of a specialized, differentiated function such as albumin synthesis, therefore, involves the coordination of many steps in the regulation of specific gene expression.

\section{Acknowledgments}

We are grateful to Dr. Nelson Ruiz-Opazo, Dr. Prasanta Chakraborty, and Dr. Bilha Raboy for their advice and assistance.

This research was supported in part by National Institutes of Health grants AM 16709, AM 17702, and Am 25350.

\section{References}

1. Mariani, G., R. Bianchi, A. Pilo, R. Palla, M. G. Toni, and L. Fusani. 1974. Albumin catabolism measurement by a double tracer technique in uremic patients during a single dialytic treatment. Eur. $J$. Clin. Invest. 4:435-442.

2. Coles, G. A., D. K. Peters, and J. H. Jones. 1970. Albumin metabolism in chronic renal failure. Clin. Sci. (Oxf.). 39:423-435.

3. Bianchi, R., G. Mariani, A. Pilo, F. Carmassi. 1976. In Plasma Protein Turnover. R. Bianchi, G. Mariani, and A. S. McFarlane, editors. The Macmillan Publishing Co., New York. 237-250. 
4. Black, M., L. Biempica, S. Goldfischer, I. M. Arias, and S. Grossman. 1977. Effect of chronic renal failure in rats on structure and function of the hepatic endoplasmic reticulum. Exp. Mol. Pathol. 27:377-391.

5. Grossman, S. B., S. H. Yap, and D. A. Shafritz. 1977. Influence of chronic renal failure on protein synthesis and albumin metabolism in rat liver. J. Clin. Invest. 59:869-878.

6. Ramsey, J. C., and W. J. Steele. 1976. A procedure for the quantitative recovery of homogeneous populations of undegraded free and bound polysomes from rat liver. Biochemistry. 15:1704-1712.

7. Yap, S. H., R. K. Strair, and D. A. Shafritz. 1977. Distribution of rat liver albumin mRNA in membrane-bound and free polyribosomes as determined by molecular hybridization. Proc. Natl. Acad. Sci. USA 74:5397-5401.

8. Yap, S. H., R. K. Strair, and D. A. Shafritz. 1978. Effect of a short term fast on the distribution of cytoplasmic albumin messenger ribonucleic acid in rat liver: evidence for formation of free albumin messenger ribonucleoprotein particles. J. Biol. Chem. 253:4944-4950.

9. Shafritz, D. A., J. W. Drysdale, and K. J. Isselbacher. 1973. Translation of liver messenger ribonucleic acid in a messenger-dependent reticulocyte cell-free system. J. Biol. Chem. 248:3220-3227.

10. Strair, R. K., S. H. Yap, and D. A. Shafritz. 1977. Use of molecular hybridization to purify and analyze albumin messenger RNA from rat liver. Proc. Natl. Acad. Sci. USA. 74:4346-4350.

11. Adams, S. L., M. E. Sobel, B. H. Howard, K. Olden, K. M. Yamada, L. Pastan, and B. de Crombrugghe. 1977. Levels of translatable mRNAs for cell surface protein, collagen precursors, and two membrane proteins are altered in Rous Sarcoma virus-transformed chick embryo fibroblasts. Proc. Natl. Acad. Sci. USA. 74:3399-3403.

12. Zern, M. A., P. R. Chakraborty, N. Ruiz-Opazo, S. H. Yap, and D. A. Shafritz. 1983. Development and use of a rat albumin cDNA clone to evaluate the effect of chronic ethanol administration on hepatic protein synthesis. Hepatology. 3:317-322.

13. Villa-Kamaroff, L., A. Efstratiadis, S. Broome, P. Lomedico, F. Tizard, S. P. Naber, W. L. Chick, and W. Gilbert. 1978. A bacterial clone synthesizing proinsulin. Proc. Natl. Acad. Sci. USA. 75:37273731.

14. Dingman, C. W., and A. C. Peacock. 1968. Analytical studies on nuclear ribonucleic acid using polyacrylamide gel electrophoresis. Biochemistry. 7:659-667.

15. Rigby, P. W., M. A. Dieckmann, C. Rhodes, and P. Berg. 1977. Labelling deoxyribonucleic acid to high specific activity in vitro by nick translation with DNA polymerase I. J. Mol. Biol. 113:237-251.

16. Thomas, P. S. 1980. Hybridization of denatured RNA and small DNA fragments transferred to nitrocellulose. Proc. Natl. Acad. Sci. USA. 77:5201-5205.

17. Bradford, M. M. 1976. A rapid and sensitive method for the quantitation of microgram quantities of protein utilizing the principle of protein-dye binding. Anal. Biochem. 72:248-254.

18. Pelham, R. B., and R. J. Jackson. 1976. An efficient mRNAdependent translation system from reticulocyte lysates. Eur. J. Biochem. 67:247-256.

19. Shields, D., and G. Blobel. 1977. Cell-free synthesis of preproinsulin and processing by heterologous mammalian microsomal membranes. Proc. Natl. Acad. Sci. USA. 74:2059-2063.

20. Strohman, R. C., P. S. Moos, J. Micou-Eastwood, D. Spector,
A. Przybyla, and B. Paterson. 1977. Messenger RNA for myosin polypeptides: isolation from single myogenic cell cultures. Cell. 10:265-273.

21. Adams, S. L., D. Boettiger, R. J. Focht, H. Holtzer, and M. Pacifici. 1982. Regulation of the synthesis of extracellular matrix components of chondroblasts transformed by a temperature-sensitive mutant of Rous Sarcoma Virus. Cell. 30:373-384.

22. Barrett, A. J. 1969. Properties of lysosomal enzymes. In Lysosomes in Biology and Pathology. J. T. Dingle and H. B. Fell, editors. NorthHolland Publishing Co., Amsterdam. 245-312.

23. McMaster, G. K., and G. G. Carmichael. 1977. Analysis of single- and double-stranded nucleic acids on polyacrylamide and agarose gels by using glyoxal and acridine orange. Proc. Natl. Acad. Sci. USA. 74:4835-4838.

24. Shafritz, D. A. 1977. Messenger RNA and its translation. In Protein Synthesis. H. Weissback and S. Pestka, editors. Academic Press, Inc., New York. 555-601.

25. Tse, T. P. H., and J. M. Taylor. 1977. Translation of albumin messenger RNA in a cell-free protein-synthesizing system derived from wheat germ. J. Biol. Chem. 252:1272-1278.

26. Enwonwu, C. O., and H. N. Munro. 1970. Rate of RNA turnover in rat liver in relation to intake of protein. Arch. Biochem. Biophys. 138:532-539.

27. Brewer, E. N., L. B. Foster, and B. H. Sells. 1969. A possible role for ribonuclease in the regulation of protein synthesis in normal and hypophysectomized rats. J. Biol. Chem. 244:1389-1392.

28. Fleck, A., J. Shepherd, and H. N. Munro. 1965. Protein synthesis in rat liver: influence of amino acids in diet on microsomes and polysomes. Science (Wash. DC). 150:628-629.

29. Sidransky, H., D. S. R. Sarma, M. Bongiorno, and E. Verney. 1968. Effect of dietary tryptophan on hepatic polyribosomes and protein synthesis in fasted mice. J. Biol. Chem. 243:1123-1132.

30. Rothschild, M. A., M. Oratz, and S. S. Schreiber. 1972. Effects of carbon tetrachloride on albumin synthesis. J. Clin. Invest. 51:23102314.

31. Kelman, L., S. J. Saunders, S. Wicht, L. Frith, A. Corrigall, R. E. Kirsch, and J. Terblanche. 1972. The effects of amino acids on albumin synthesis by the isolated perfused rat liver. Biochem. J. 129:805809.

32. Rothschild, M. A., M. Oratz, and S. S. Schreiber. 1974. Alcohol, amino acids, and albumin synthesis. Gastroenterology. 67:1200-1213.

33. Gaetani, S., D. Massotti, and M. A. Spadoni. 1969. Studies of dietary effects on free and membrane-bound polysomes in rat liver. Nutrition. 99:307-314.

34. Blobel, G., and B. Dobberstein. 1975. Transfer of proteins across membranes. I. Presence of proteolytically processed and unprocessed nascent immunoglobulin light chains on membrane-bound ribosomes of murine myeloma. J. Cell Biol. 67:835-851.

35. Guyette, W. A., R. J. Matusik, and J. M. Rosen. 1979. Prolactinmediated transcriptional and post-transcriptional control of casein gene expression. Cell. 17:1013-1023.

36. Palmiter, R. D., and N. H. Carey. 1974. Rapid inactivation of ovalbumin messenger ribonucleic acid after acute withdrawal of estrogen. Proc. Natl. Acad. Sci. USA. 71:2357-2361.

37. Lowenhaupt, K., and J. B. Lingrel. 1978. A change in the stability of globin mRNA during the induction of murine erythroleukemia cells. Cell. 14:337-344. 